\title{
EFFECTS OF NITROGEN FERTILIZATION RATES ON FORAGE YIELD AND QUALITY OF ANNUAL RYEGRASS (LOLIUM MULTIFLORUM L.) IN CENTRAL BLACK SEA CLIMATIC ZONE IN TURKEY
}

\author{
CINAR, S. ${ }^{1,2^{*}}-$ OZKURT, M. ${ }^{3}-$ CETIN, R. ${ }^{4}$ \\ ${ }^{1}$ Department of Plant and Animal Production, Technical Vocational School, Kilis 7 Aralik \\ University, Kilis, Turkey \\ ${ }^{2}$ Department of Horticulture and Field Crops, Faculty of Agriculture, Kyrgyz-Turkish Manas \\ University, Bishkek, Kyrgyzstan \\ ${ }^{3}$ Mus Alparslan University, Faculty of Applied Sciences, Mus, Turkey \\ ${ }^{4}$ Gaziosmanpasa University, Graduate School of Natural and Applied Sciences, Tokat, Turkey \\ *Corresponding author \\ e-mail:scinar01@hotmail.com; selahattin.cinar@manas.edu.kg
}

(Received $6^{\text {th }}$ Sep 2019; accepted $4^{\text {th }}$ Dec 2019)

\begin{abstract}
In this research, we aimed to determine the effects of nitrogen fertilization on forage yield and forage quality of annual ryegrass (Lolium multiflorum L.) in Kazova, Tokat/Turkey conditions (the Central Black Sea Climate Zone) in 2014/2015 and 2015/2016 growing years. The experiment consisted of four replications in randomized complete block design to test effect of seven nitrogen rates $(0,50,100$, $150,200,250,300 \mathrm{~kg} \mathrm{ha}^{-1}$ ) on plant height (PH), fresh forage yield (FFY), dry matter yield (DMY), crude protein ratio (CP), crude protein yield (CPY), Acid Detergent Fiber (ADF) ratio, Neutral Detergent Fiber (NDF) ratio, digestible dry matter ratio (DDM), digestible dry matter yield (DDMY), and relative feed value (RFV). The results revealed that the highest plant height $(86.7 \mathrm{~cm})$ was at the $200 \mathrm{~kg} \mathrm{ha}^{-1}$ of nitrogen rate, highest fresh forage yield $\left(48360 \mathrm{~kg} \mathrm{ha}^{-1}\right)$, dry matter yield $\left(13325 \mathrm{~kg} \mathrm{ha}^{-1}\right)$, crude protein yield $\left(1870 \mathrm{~kg} \mathrm{ha}^{-1}\right)$ and digestible dry matter yield $\left(8340 \mathrm{~kg} \mathrm{ha}^{-1}\right)$ was obtained at the $250 \mathrm{~kg} \mathrm{ha}^{-1}$ of nitrogen rate, and the highest digestible dry matter rate $(62.72 \%)$ was determined at the $150 \mathrm{~kg} \mathrm{ha}^{-1}$ nitrogen rate. Thus, $250 \mathrm{~kg} \mathrm{ha}^{-1}$ nitrogen rate was the optimal dose for high forage yield and increasing nitrogen doses did not affect the ADF and NDF rates. Nevertheless, application of $300 \mathrm{~kg} \mathrm{ha}^{-1}$ of nitrogen decreased yield but increased crude protein yield. Therefore, a nitrogen fertilization rate of $250 \mathrm{~kg} \mathrm{ha}^{-1}$ is recommended for high forage yield of annual ryegrass (Lolium multiflorum L.) in the Central Black Sea Climate Zone or similar climatic conditions.
\end{abstract}

Keywords: $A D F, N D F, D M Y, D D M Y, R F V$

\section{Introduction}

Cost of animal derived food and food products are high in Turkey. One of the most important reasons for this is the insufficient production of high quality roughage. In order to meet the high quality roughage requirement in Turkey, it is necessary to improve the meadow pastures, increase the forage crop production areas, introduce other cheap and alternative roughage resources to animal production systems, and transfer the quality roughage production techniques to the producers (Serin and Tan, 2001).

Forage crop cultivation is one of the strategies to meet the high quality roughage need of the country's livestock. Forage legumes are the source of protein and forage grasses are the source of carbohydrates in animal diet. The annual forage grass Lolium 
multiflorum L. is one of the grasses with highest forage production potential and fertilizer use efficiency (Acikgoz, 2001). The annual ryegrass is also known as annual ryegrass since it was initially cultivated in Italy as a annual forage crop.

Annual ryegrass, which is a grassy forage plant of Southern Europe origin, is a oneyear species cultivated in the genera Lolium (Genckan, 1983). It is an important alternative source of roughage in cool and temperate climates, in areas where barley and oats from winter cool climate cereals are grown for feed production. Under normal conditions, green yields varying from 15000 to $25000 \mathrm{~kg} \mathrm{ha}^{-1}$ per hectare and hay yields of 5000-8000 kg ha-1 can be obtained. In areas where water is sufficient, it is harvested 2-3 times, 40000-60000 $\mathrm{kg} \mathrm{ha}^{-1}$ green, 7500-15000 kg ha-1 dry grass can be taken (Baytekin et al. 2009).

In general, the crop is harvested and fed to livestock freshly; however, it can also be utilized as hay or silage. Annual forage grass production in Turkey has increased in recent years owing to the government subsidies for forage crops. The cultivation area of $4.832 \mathrm{da}$ and green grass production of 17.023 tons in 2014 has increased to a cultivation area 103.410 da and green grass production of 448.086 tons in 2019 (TUIK, 2019).

In order to achieve the expected yield and quality of forage crops, the plants should be fertilized with the appropriate combination and rate in the required period. In addition to yield, forage quality is also of great importance for animal health. Nitrogen, which is the most important nutrient for plants, constitutes the majority of dry matter. In addition, nitrogen is incorporated to proteins, chlorophyll, enzymes, and vitamins in plants. Nitrogen is the most commonly used nutrient in grasses. Appropriate amounts of nitrogenous fertilizers increase the protein content in grasses, but the use of excess nitrogen in plants also leads to the accumulation of nitrate and alkaloids. A positive response was reported in annual ryegrass with the application of nitrogen fertilizers (Colak, 2015; Ozdemir et al., 2019).

Different results have been obtained in studies on fertilizer use on annual ryegrass. Celen (1991) reported that the highest yields were achieved at 100 and $150 \mathrm{~kg} \mathrm{ha}^{-1}$ nitrogen (N) application in Bornova, İzmir/Turkey conditions. Seker (1992) realized highest dry matter and crude protein yields $200 \mathrm{~kg} \mathrm{ha}^{-1} \mathrm{~N}$ and the highest crude protein ratio at the rate of $250 \mathrm{~kg} \mathrm{ha}^{-1} \mathrm{~N}$ application rate in trials in Erzurum/Turkey. Parlak et al. (2007) indicated the highest fresh forage yield $\left(11630 \mathrm{~kg} \mathrm{ha}^{-1}\right)$, dry matter $\left(3840 \mathrm{~kg} \mathrm{ha}^{-1}\right)$ and crude protein yield $\left(800 \mathrm{~kg} \mathrm{ha}^{-1}\right)$ at $200 \mathrm{~kg} \mathrm{ha}^{-1} \mathrm{~N}$ application in Ankara/Turkey. In a study carried out in Serbia, Simic et al. (2009) reported that the highest dry matter yield varied between years and achieved in $\mathrm{N}$ application rates of 50$150 \mathrm{~kg} \mathrm{ha}^{-1}$. Kesiktas (2010) reported the highest dry matter yield at the application of 100 to $150 \mathrm{~kg} \mathrm{ha}^{-1}$ of $\mathrm{N}$ and the highest crude protein ratio at the $150 \mathrm{~kg} \mathrm{ha}^{-1} \mathrm{~N}$ applications in Karaman/Turkey conditions. Pavinato et al. (2014) reported that the increase in the $\mathrm{N}$ rate increased dry matter and crude protein yield and the best results were attained from the dose of $120 \mathrm{~kg} \mathrm{ha}^{-1}$ of $\mathrm{N}$ in Brazil. Colak (2015) declared $80 \mathrm{~kg} \mathrm{ha}^{-1}$ of $\mathrm{N}$ being sufficient to achieve high yield in Ankara and Ozdemir et al. (2019) reported that $500 \mathrm{~kg} \mathrm{ha}^{-1}$ of $\mathrm{N}$ was suitable for high yield and high quality product of annual forage grass in in a study conducted in Bursa/Turkey.

Annual ryegrass, high growth rate and nitrogen absorption in fertilization due to the ability to (Ozkul et al., 2012) is an alternative forage crops can be obtained high yield. Turkey and Turkey's Central Black Sea region is a plant that has the potential to close the fodder deficit in the region. 
The purpose of the study, Turkey's Central Black Sea Region in the efficiency and high level of quality forage in closing the deficit will be an alternative forage crops in one annual ryegrass (Lolium multiflorum L.) to determine the appropriate nitrogen levels.

\section{Materials and Method}

\section{Materials}

The experimental trial was established in the Research and Application Center of Faculty of Agriculture located at Tasliciftlik Campus of Gaziosmanpasa University in Tokat Turkey for two years, 2014-2015 and 2015-2016 growing seasons. Trial area was $598 \mathrm{~m}$ above the sea level, at the $40^{\circ} 19^{\prime} 58.17$ North latitude and $36^{\circ} 28^{\prime} 05$ East longitude (Figure 1).

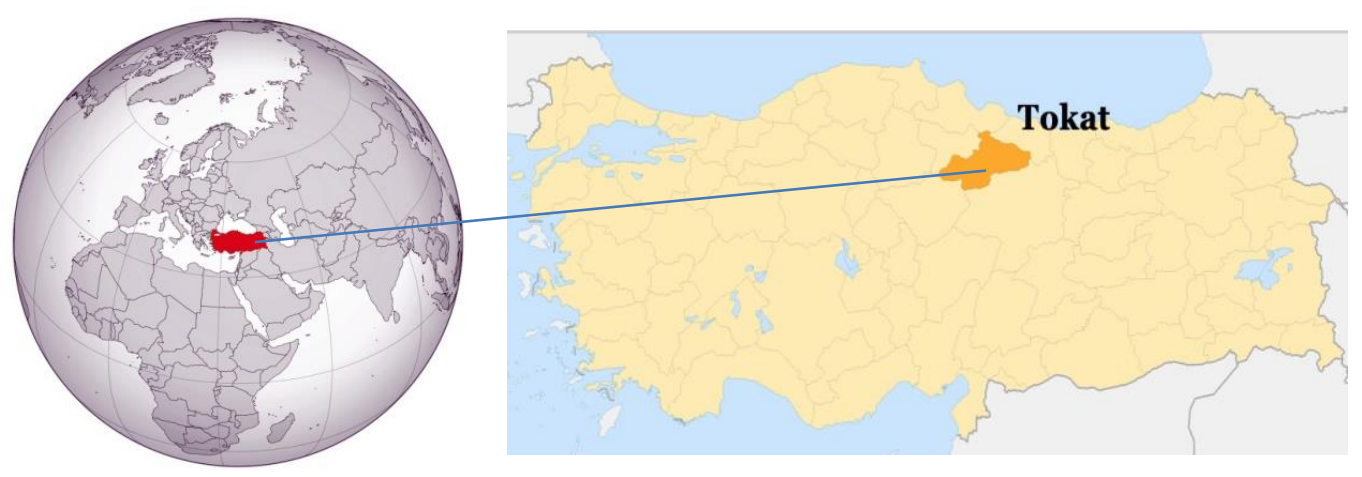

Figure 1. Geographic location of the field trial

Long term average rainfall, temperature, and relative humidity records of the research place was gathered compared to the temperature $\left({ }^{\circ} \mathrm{C}\right)$, monthly total rainfall $(\mathrm{mm})$ and monthly average relative humidity $(\%)$ of the breeding periods in which the experiment was conducted. The average temperatures of breeding periods $(2014-2015,2015-2016)\left(13.6,12.0^{\circ} \mathrm{C}\right)$ in which the experiment was carried out were higher than the average long-term temperature $\left(11.7^{\circ} \mathrm{C}\right)$, and total rainfall in the first breeding period $(419.4 \mathrm{~mm})$ is lower than the long year average $(428.5 \mathrm{~mm})$ and higher in the second breeding period $(463.4 \mathrm{~mm})$ than long year average. In addition, the relative humidity in the in the first breeding period (57.0\%) is lower than the long year average $(59.6 \%)$ and higher in the second breeding period $(63.7 \%)$ than long year average (Anonymous, 2017). According to this, it can be concluded that the years in which the experiment was conducted were hotter and rainfall and humidity also different than the long-term averages (Table 1).

Chemical analyses of soil samples taken from 0-20 and 20-40 cm depths in the research area were carried out in Gaziosmanpasa University, Faculty of Agriculture, Department of Soil Science. According to the analysis results, the soil of the trial area was found to be poor in terms of organic matter, potassium, and lime, and it was clayey alkaline (Kacar, 2016).

In the research, Caramba cultivar (Lolium multiflorum cv. Caramba) was used and seven doses of nitrogen $\left(0,50,100,150,200,250,300 \mathrm{~kg} \mathrm{ha}^{-1}\right)$ were evaluated. 
Table 1. Climate data for breeding periods (2014-2015, 2015-2016) and long year average of the region where the research was conducted

\begin{tabular}{c|c|c|c|c|c|c|c|c|c}
\hline \multirow{2}{*}{ Aylar } & \multicolumn{3}{|c|}{ Temperature $\left({ }^{\circ} \mathbf{C}\right)$} & \multicolumn{3}{c|}{ Precipitation (mm) } & \multicolumn{3}{c}{ Relative Humidity (\%) } \\
\cline { 2 - 9 } & $\begin{array}{c}\mathbf{2 0 1 4 -} \\
\mathbf{2 0 1 5}\end{array}$ & $\begin{array}{c}\mathbf{2 0 1 5}- \\
\mathbf{2 0 1 6}\end{array}$ & $\mathbf{L Y A}$ & $\begin{array}{c}\mathbf{2 0 1 4}- \\
\mathbf{2 0 1 5}\end{array}$ & $\begin{array}{c}\mathbf{2 0 1 5}- \\
\mathbf{2 0 1 6}\end{array}$ & LYA & $\begin{array}{c}\mathbf{2 0 1 4 -} \\
\mathbf{2 0 1 5}\end{array}$ & $\begin{array}{c}\mathbf{2 0 1 5 -} \\
\mathbf{2 0 1 6}\end{array}$ & LYA \\
\hline September & 20.2 & 22.9 & 18.8 & 39.0 & 0.2 & 18.5 & 54.2 & 49.6 & 56.2 \\
October & 14.1 & 15.1 & 13.7 & 51.6 & 55.6 & 38.8 & 68.5 & 69.2 & 58.6 \\
November & 7.1 & 8.6 & 7.9 & 63.1 & 15.8 & 44.1 & 73.1 & 65.6 & 52.2 \\
December & 7.0 & 1.0 & 3.8 & 39.4 & 35.5 & 46.6 & 75.6 & 81.6 & 70.1 \\
January & 4.1 & 2.4 & 1.9 & 38.4 & 104.6 & 41.4 & 68.6 & 69.0 & 74.8 \\
February & 8.0 & 5.2 & 3.5 & 25.8 & 42.6 & 34.0 & 49.6 & 62.5 & 65.0 \\
March & 11.1 & 8.1 & 7.4 & 57.0 & 49.4 & 40.7 & 50.7 & 65.6 & 54.8 \\
April & 16.2 & 10.0 & 12.5 & 34.5 & 23.4 & 55.4 & 43.0 & 58.3 & 47.8 \\
May & 17.5 & 16.9 & 16.5 & 34.8 & 89.5 & 58.5 & 57.4 & 57.1 & 62.4 \\
June & 20.3 & 19.9 & 19.9 & 35.6 & 33.1 & 38.3 & 57.0 & 63.7 & 59.6 \\
July & 24.2 & 22.1 & 22.3 & 0.2 & 13.7 & 12.2 & 49.4 & 55.0 & 55.4 \\
\hline Average/Total & 13.6 & 12.0 & 11.7 & 419.4 & 463.4 & 428.5 & 58.8 & 63.3 & 59.7 \\
\hline
\end{tabular}

LYA: Long Year Average

\section{Method}

The experiment consisted of four replications in randomized complete block design (RCBD) with seven plots in each replication. Each plot consisted of 6 rows with $5 \mathrm{~m}$ length and $20 \mathrm{~cm}$ row spacing. Plants were seeded at $2-3 \mathrm{~cm}$ planting depth in 1st year on 16 October 2014 and 2nd year on 12 October 2015. In the experiment, the plot sizes were determined as $1.2 \times 5 \mathrm{~m}=6 \mathrm{~m}^{2}$ (Avcioglu and Geren, 1996).

Sowing was based on $30 \mathrm{~kg} \mathrm{ha}^{-1}$ seed amount (Acikgoz, 2001). Seeds weighed for each row were planted by hand in rows opened by marker. About $1 / 4$ of the predetermined nitrogen rate was applied after planting, another $1 / 4$ was applied during the tillering, $1 / 4$ was applied after the first harvest, and last $1 / 4$ was applied after the second harvest (Kesiktas, 2010). TSP (Triple Super Phosphate) was used as phosphorus fertilizer and urea was used as nitrogen fertilizer in the experiment. Pure $50 \mathrm{~kg} \mathrm{ha}^{-1}$ phosphorus was applied to each parcel in planting (Kusvuran and Tansi, 2005). In both years, plots were harvested three times and irrigation was performed after the harvests.

The general view of the trial parcels is shown in Figure 2.
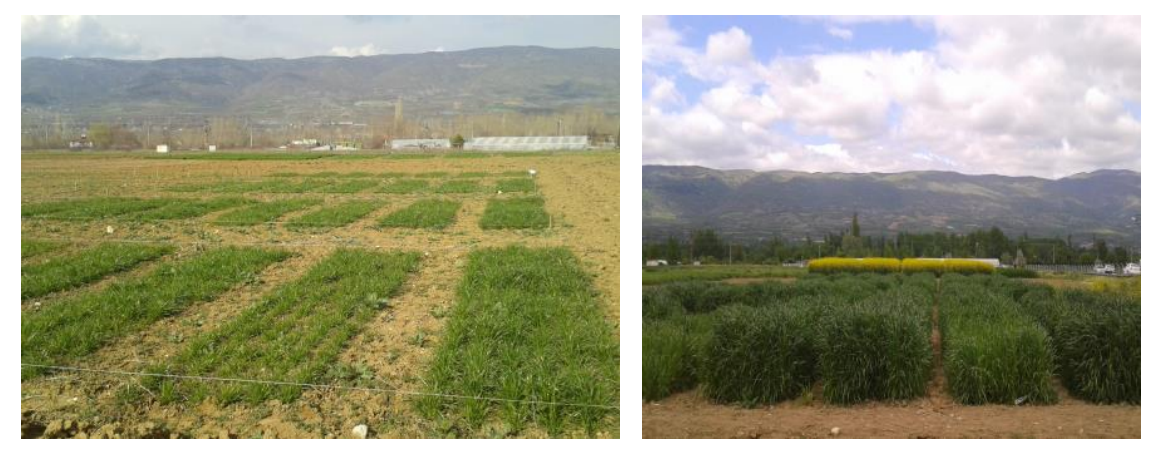

Figure 2. General views from trial parcels in different periods

The height of the 10 plants randomly selected from each plot were measured from the soil surface to the highest point of the plant and the plot based plant height was determined by taking the mean of the measured plants. The plots were harvested during 
the beginning of heading (10\% heading). One row from the edges of each plot, top and bottom $0.5 \mathrm{~m}$ was mowed and removed, the remaining area was harvested. The fresh biomass obtained from each plot was weighed and converted to the fresh forage yield per ha (Anonymous, 2001). A randomly selected $500 \mathrm{~g}$ fresh forage sample was dried to a constant weight at $60^{\circ} \mathrm{C}$ and dry weights ratios were determined based on dried samples (Sleugh et al., 2000). Samples of $5 \mathrm{~g}$ from the dried herbages were dried further for 24 hours in the oven set at $105^{\circ} \mathrm{C}$, cooled in a desiccator, and subsequently weighed on sensitive a balance to determine the dry matter ratios. Dry matter yields were calculated based on the obtained dry matter ratio. Some of the samples dried at $60^{\circ} \mathrm{C}$ were ground and nitrogen was determined in the grass samples by Kjeldahl method. Determined nitrogen values were multiplied by 6.25 conversion coefficient to determine crude protein contents (\%) of the of samples (Tan, 1995). In the experiment, ADF (Acid Detergent Fiber) and NDF (Neutral Detergent Fiber) analyses were performed, according to Van Soest et al. (1991) using the ANKOM 200/220 device.

Digestible dry matter ratio, ADF composition, relative feed value (RFV), dry matter consumption values were calculated using formulas (Eq.1, Eq.2, Eq.3) provided by Sheaffer et al. (1995).

$$
\begin{gathered}
\text { Digestible Dry Matter }(\mathrm{DDM})=88.9-(0.779 x \% \text { ADF }) \\
\text { Dry Matter Intake }(\mathrm{DMI})=120 /(\% \mathrm{NDF})
\end{gathered}
$$$$
\text { Relative Feed Value }=(\% \mathrm{DDM} \times \% \mathrm{DMI}) / 1.29
$$

The digestible dry matter yield was obtained by multiplying the dry matter yield with the digestible dry matter ratio and the crude protein yield was obtained by multiplying the crude protein ratios and the dry matter yield.

The variance analysis (ANOVA) of the data was performed in the first year, second year and combined randomized block experiment design in MSTATC statistical program. Mean separations of significant traits were conducted using Duncan's multiple comparison test (Duzgunes et al., 1987).

\section{Results and Discussion}

The table of the variance analysis of the combined data is as follows (Table 2).

Table 2. Results of analysis of variance and mean squares of the traits determined

\begin{tabular}{c|c|c|c|c|c|c|c|c|c|c|c}
\hline & DF & PH & FFY & DMY & CP & CPY & ADF & NDF & DDM & DDMY & RFV \\
\hline Year (Y) & 1 & 45.2 & 1998788.8 & $352126.9^{*}$ & 0.03 & $6393.3^{*}$ & $4.7^{*}$ & 9.8 & $2.9^{*}$ & $153911.4^{*}$ & 90.6 \\
Error 1 & 6 & 8.8 & 640803.8 & 30728.0 & 0.70 & 844.7 & 0.7 & 5.7 & 0.4 & 12838.03 & 34.9 \\
Nitrogen (N) & 6 & $39.3 * *$ & $1342460.5 * *$ & $102591.8^{* *}$ & $6.32^{* *}$ & $3626.2^{* *}$ & $2.2^{*}$ & $10.2^{*}$ & $1.3^{*}$ & $40573.4^{* * *}$ & $65.8^{* *}$ \\
NxY & 6 & 5.5 & 92145.4 & 7161.7 & 0.20 & 153.21 & 1.0 & 3.5 & 0.6 & 2486.7 & 14.7 \\
Error 2 & 36 & 11.8 & 1980817.8 & 9564.9 & 0.38 & 265.7 & 0.9 & 3.4 & 0.6 & 3458.7 & 18.5 \\
\hline CV & & 4.1 & 10.2 & 8.5 & 4.5 & 10.4 & 2.8 & 3.4 & 1.2 & 8.2 & 4.0 \\
\hline
\end{tabular}

DF: Degree of freedom; ${ }^{*} \mathrm{P}<0.05$ and ${ }^{* *} \mathrm{P}<0.01$

According to the variance analysis, combined data of two years made a significant statistical difference in nitrogen applications, plant height, fresh forage yield, dry matter 
yield, crude protein yield, ADF, NDF, DDM, crude protein yield, DDMY and RFV. Nitrogen applications were found to be statistically significant in dry matter yield, crude protein yield, ADF, DDM, DDMY between years. Nitrogen x year interaction was not statistically significant in any parameter.

\section{Plant Height (cm)}

According to the ANOVA results, the nitrogen rate has a significant effect on plant height values of the first year and two-year average. However, nitrogen rates did not affect plant height of annual ryegrass in the second year. The average plant height values determined in the plots with different nitrogen rates are shown in Table 3.

Although the average plant height in the second year was higher than the first year, it was found that year effect was not statistically significant. In the first year and two-year averages, plant height was significantly higher in the plots where nitrogen was applied compare to the control group. Nitrogen dose applied to annual ryegrass increased the plant height (Table 3). This increase can be attributed to the vegetative growth stimulating effect of nitrogen fertilizers in plants (Kun, 1994; Gokmen et al., 2001).

Table 3. Average plant height values (cm) of annual ryegrass based on nitrogen fertilizer rates

\begin{tabular}{c|c|c|c}
\hline \multirow{2}{*}{$\begin{array}{c}\text { Nitrogen } \\
\text { (kg ha-1) }^{-1}\end{array}$} & $\mathbf{2 0 1 5}$ & $\mathbf{2 0 1 6}$ & Mean \\
\cline { 2 - 4 } & $76.9 \mathrm{~b}^{* *}$ & 82.1 & $79.5 \mathrm{~b}$ \\
50 & $83.2 \mathrm{a}$ & 84.3 & $83.7 \mathrm{a}$ \\
100 & $83.0 \mathrm{a}$ & 85.3 & $84.1 \mathrm{a}$ \\
150 & $83.8 \mathrm{a}$ & 85.7 & $84.8 \mathrm{a}$ \\
200 & $86.6 \mathrm{a}$ & 86.8 & $86.7 \mathrm{a}$ \\
250 & $84.8 \mathrm{a}$ & 85.5 & $85.2 \mathrm{a}$ \\
300 & $83.0 \mathrm{a}$ & 84.4 & $83.7 \mathrm{a}$ \\
\hline Mean & 83.1 & 84.9 & \\
\hline
\end{tabular}

** Values within the same columns followed by different letters are significantly different based on Duncan's test at $\mathrm{P}<0.01$

The average plant height of annual ryegrass was reported to be $60-90 \mathrm{~cm}$ by Erkun (1954), 65.7-68.6 $\mathrm{cm}$ by Kusvuran and Tansi (2005), $48.4 \mathrm{~cm}$ by Demiroglu et al. (2007), $64.5 \mathrm{~cm}$ by Kesiktas (2010), $88.4 \mathrm{~cm}$ by Cinar et al. (2011), 50.1-68.3 $\mathrm{cm}$ by Colak and Sancak (2017). The plant height measurement in the present study was closer to the values reported in the study of Cinar et al. (2011) and deviated from the other studies. This may be due to the variations in ecological conditions, cultivation techniques and the cultivars tested.

\section{Fresh Forage Yield $\left(\mathrm{kg} \mathrm{ha}^{-1}\right)$}

Difference in the nitrogen rate had a significant effect on fresh forage yield of annual ryegrass in both years and in the mean of the two years. The average fresh forage yield values based on the nitrogen rates are given in Table 4.

As shown in Table 4, fresh forage yield ranged from $32330 \mathrm{~kg} \mathrm{ha}^{-1}$ to $46150 \mathrm{~kg} \mathrm{ha}^{-1}$ in the first year, from $40420 \mathrm{~kg} \mathrm{ha}^{-1}$ to $50570 \mathrm{~kg} \mathrm{ha}^{-1}$ in the second year, and from $36375 \mathrm{~kg} \mathrm{ha}^{-1}$ to $48360 \mathrm{~kg} \mathrm{ha}^{-1}$ in the two-year average depending on the fertilizer rate applied. In the first year, second year and two-year average, the highest fresh forage yield was obtained from the application of nitrogen rate of $250 \mathrm{~kg} \mathrm{ha}^{-1}$. However, fresh 
forage yield obtained from the nitrogen rates between $50-200 \mathrm{~kg} \mathrm{ha}^{-1}$ in the first year, from the nitrogen rates of $150-200 \mathrm{~kg} \mathrm{ha}^{-1}$ in the second year, and from the nitrogen rates between 150-200 kg ha-1 at the two-year averages were not significantly different from that of the nitrogen rate of $250 \mathrm{~kg} \mathrm{ha}^{-1}$. In both years separately and on a two-year average, the nitrogen rate of $300 \mathrm{~kg} \mathrm{ha}^{-1}$ decreased fresh forage weight.

Table 4. Fresh forage yield values $\left(\mathrm{kg} \mathrm{ha}^{-1}\right)$ of annual ryegrass based on nitrogen fertilizer rates

\begin{tabular}{c|l|l|l}
\hline \multirow{2}{*}{$\begin{array}{c}\text { Nitrogen } \\
\left(\mathbf{k g ~ h a}^{-1}\right)\end{array}$} & $\mathbf{2 0 1 5}$ & $\mathbf{2 0 1 6}$ & Mears \\
\cline { 2 - 4 } & $32330 \mathrm{~b} \mathrm{~b}^{* *}$ & $40420 \mathrm{~d}$ & $36375 \mathrm{~d}$ \\
50 & $41150 \mathrm{a}$ & $44520 \mathrm{bcd}$ & $42835 \mathrm{bc}$ \\
100 & $38510 \mathrm{ab}$ & $42670 \mathrm{bcd}$ & $40590 \mathrm{~cd}$ \\
150 & $43790 \mathrm{a}$ & $45790 \mathrm{abc}$ & $44790 \mathrm{abc}$ \\
200 & $45930 \mathrm{a}$ & $47760 \mathrm{ab}$ & $46845 \mathrm{ab}$ \\
250 & $46150 \mathrm{a}$ & $50570 \mathrm{a}$ & $48360 \mathrm{a}$ \\
300 & $39660 \mathrm{ab}$ & $42230 \mathrm{~cd}$ & $40945 \mathrm{~cd}$ \\
\hline Mean & 41074 & 44851 & \\
\hline
\end{tabular}

** Values within the same columns followed by different small letters are significantly different based on Duncan's test at $\mathrm{P}<0.01$

The fresh forage yield of the annual ryegrass was reported to be $5500 \mathrm{~kg} \mathrm{ha}^{-1}$ with the application of $150 \mathrm{~kg} \mathrm{ha}^{-1}$ nitrogen (Alvim and Moojen, 1984), $13500.0 \mathrm{~kg} \mathrm{ha}^{-1}$ with $55 \mathrm{~kg} \mathrm{ha}^{-1}$ nitrogen application (Kallenbach et al., 2003), $11630 \mathrm{~kg} \mathrm{ha}^{-1}$ with $200 \mathrm{~kg} \mathrm{ha}^{-1}$ nitrogen application (Bright et al., 2006), $15430 \mathrm{~kg} \mathrm{ha}^{-1}$ with $65 \mathrm{~kg}^{-1}$ nitrogen application (Piskin, 2007), $32450 \mathrm{~kg} \mathrm{ha}^{-1}$ with $200 \mathrm{~kg} \mathrm{ha}^{-1}$ nitrogen application (Kusvuran and Tansi, 2005), 19270, 19320, $19320 \mathrm{~kg} \mathrm{ha}^{-1}$ with 40, 80, $120 \mathrm{~kg} \mathrm{ha}^{-1}$ of nitrogen dose applications, respectively (Colak and Sancak, 2017).

When compared with the abovementioned previous research, it is evident that both fresh forage yield values and nitrogen rates vary greatly. This discrepancy may be due to differences in the nature of the studies, ecology, nitrogen rate, and the cultivar tested.

\section{Dry Matter Yield $\left(\mathrm{kg} \mathrm{ha}^{-1}\right)$}

According to the ANOVA results for dry matter yield values, different nitrogen fertilizer rates had a significant effect on dry matter yield in the first year, second year, and two-year average. Average dry matter yield values in respect to nitrogen rates are given in Table 5.

Depending on the fertilizer rates applied, dry matter yield ranged from $8590 \mathrm{~kg} \mathrm{ha}^{-1}$ to $12410 \mathrm{~kg} \mathrm{ha}^{-1}$ in the first year, $11340 \mathrm{~kg} \mathrm{ha}^{-1}$ to $14240 \mathrm{~kg} \mathrm{ha}^{-1}$ in the second year, and $9965 \mathrm{~kg} \mathrm{ha}^{-1}$ to $13325 \mathrm{~kg} \mathrm{ha}^{-1}$ when means were averaged over two years. The highest dry matter yield in the first year, second year and two-year average was obtained from the application of $250 \mathrm{~kg} \mathrm{ha}^{-1}$ nitrogen rate. Dry matter yield decreased at $300 \mathrm{~kg} \mathrm{ha}^{-1}$ nitrogen rate for each of the two years and on average. Dry matter yield in the second year was significantly higher than that in the first year (Table 4). The reason for the higher average dry matter yield in the second year is higher rainfall in the second year (Table 1).

In general, dry matter yield results were parallel to fresh forage yield (Table 4) as expected. The earlier research revealed that dry matter yield of annual ryegrass was $9600 \mathrm{~kg} \mathrm{ha}^{-1}$ when $350 \mathrm{~kg} \mathrm{ha}^{-1}$ nitrogen fertilizer is applied (Corainville et al., 1973), 
was $8760 \mathrm{~kg} \mathrm{ha}^{-1}$ with $90 \mathrm{~kg} \mathrm{ha}^{-1}$ nitrogen application (Bartholomew and Williams, 1978), was $2020 \mathrm{~kg} \mathrm{ha}^{-1}$ with $55 \mathrm{~kg} \mathrm{ha}^{-1}$ nitrogen application (Piskin, 2007). In the research reported here, the highest dry matter yield was obtained with the application of $250 \mathrm{~kg} \mathrm{ha}^{-1}$ pure nitrogen. There is a discrepancy between our results and the previous results listed above. Different ecological conditions, variation in the rate of fertilizer, management differences and the difference in cultivar may have led the discrepancy among reported results.

Table 5. Average dry matter yield values $\left(\mathrm{kg} \mathrm{ha}^{-1}\right)$ of annual ryegrass based on nitrogen fertilizer rates

\begin{tabular}{c|c|c|c}
\hline \multirow{2}{*}{$\begin{array}{c}\text { Nitrogen } \\
\left.\mathbf{( k g ~ h a}^{-1}\right)\end{array}$} & \multicolumn{3}{|c}{ Years } \\
\cline { 2 - 4 } & $\mathbf{2 0 1 5}$ & $\mathbf{2 0 1 6}$ & Mean \\
\hline 0 & $8590 \mathrm{~d}^{* *}$ & $11340 \mathrm{c}$ & $9965 \mathrm{e}$ \\
50 & $10510 \mathrm{bc}$ & $12070 \mathrm{bc}$ & $10615 \mathrm{~cd}$ \\
100 & $9830 \mathrm{~cd}$ & $11400 \mathrm{c}$ & $11870 \mathrm{bc}$ \\
150 & $11190 \mathrm{abc}$ & $12550 \mathrm{bc}$ & $12425 \mathrm{ab}$ \\
200 & $11870 \mathrm{ab}$ & $12980 \mathrm{ab}$ & $13325 \mathrm{a}$ \\
250 & $12410 \mathrm{a}$ & $14240 \mathrm{a}$ & $11080 \mathrm{~cd}$ \\
300 & $10620 \mathrm{bc}$ & $11540 \mathrm{bc}$ & \\
\hline Mean & $10717 \mathrm{~B}^{+}$ & $12303 \mathrm{~A}$ & \\
\hline
\end{tabular}

** Values within the same columns followed by different letters are significantly different based on Duncan's test at $\mathrm{P}<0.01$.

${ }^{+}$Values within the same row followed by different capital letters are significantly different based on

Duncan's test at $\mathrm{P}<0.05$

\section{Crude Protein Ratio (\%)}

ANOVA results for crude protein ratio based on different nitrogen rates revealed that nitrogen rates had a significant effect on the crude protein ratio in the first year, second year and on the two-year averages. Average crude protein ratios determined according to nitrogen rates are provided in Table 6.

The ratio of crude protein, one of the most important forage quality parameter, increased in parallel to the increase in the nitrogen rate in annual ryegrass. The highest crude protein content was obtained from $300 \mathrm{~kg} \mathrm{ha}^{-1}$ nitrogen rate in both trial years and in two-year average. It has been stated by many researchers that nitrogen increases the crude protein content of annual grasses (Colak, 2015).

In the previous research, the highest crude protein ratio was reported at 200 and $250 \mathrm{~kg} \mathrm{ha}^{-1}$ nitrogen application in Kusvuran and Tansi (2005), at $150 \mathrm{~kg} \mathrm{ha}^{-1}$ nitrogen application in Simic et al. (2009) and Kesiktas (2010), at $470 \mathrm{~kg} \mathrm{ha}^{-1}$ nitrogen application in Kusvuran (2011), and at $200 \mathrm{~kg} \mathrm{ha}^{-1}$ nitrogen application in Colak (2015). When the results obtained here are compared with the abovementioned studies, no concordance is observed. Different ecological conditions, variation in the rate of fertilizer, management differences along with the difference in tested cultivars may have led this difference.

\section{Crude Protein Yield $\left(\mathrm{kg} \mathrm{ha}^{-1}\right)$}

One way ANOVA results discerned that the crude protein yield significantly differ with the various fertilizer rates in the first year, second year, and two-year average. Average crude protein yields determined according to nitrogen rates are listed in Table 7. 
Table 6. Determination of the crude protein ratio (\%) of annual ryegrass based on nitrogen fertilizer rates

\begin{tabular}{c|c|c|c}
\hline \multirow{2}{*}{$\begin{array}{c}\text { Nitrogen } \\
\left(\mathbf{k g ~ h a}^{-1}\right)\end{array}$} & $\mathbf{2 0 1 5}$ & $\mathbf{2 0 1 6}$ & Mean \\
\cline { 2 - 4 } & $11.91 \mathrm{~b}^{* *}$ & $12.37 \mathrm{~d}$ & $12.14 \mathrm{~d}$ \\
\hline 0 & $12.70 \mathrm{~b}$ & $12.99 \mathrm{~cd}$ & $12.85 \mathrm{c}$ \\
100 & $13.93 \mathrm{a}$ & $13.61 \mathrm{bc}$ & $13.77 \mathrm{~b}$ \\
150 & $14.12 \mathrm{a}$ & $14.15 \mathrm{ab}$ & $14.13 \mathrm{~b}$ \\
200 & $13.83 \mathrm{a}$ & $13.43 \mathrm{bc}$ & $13.63 \mathrm{~b}$ \\
250 & $13.96 \mathrm{a}$ & $14.02 \mathrm{~b}$ & $13.99 \mathrm{~b}$ \\
300 & $14.75 \mathrm{a}$ & $14.96 \mathrm{a}$ & $14.86 \mathrm{a}$ \\
\hline Mean & 13.60 & 13.65 & \\
\hline
\end{tabular}

** Values within the same columns followed by different small letters are significantly different based on Duncan's test at $\mathrm{P}<0.01$

Table 7. Average crude protein yield values $\left(\mathrm{kg} \mathrm{ha}^{-1}\right)$ of annual ryegrass based on nitrogen fertilizer rates

\begin{tabular}{c|c|c|c}
\hline \multirow{2}{*}{$\begin{array}{c}\text { Nitrogen } \\
\left.\mathbf{( k g ~ h a}^{-1}\right)\end{array}$} & $\mathbf{2 0 1 5}$ & $\mathbf{2 0 1 6}$ & Mean \\
\cline { 2 - 4 } & $1030 \mathrm{c}^{* *}$ & $1400 \mathrm{c}$ & $1220 \mathrm{~d}$ \\
\hline 0 & $1340 \mathrm{~b}$ & $1570 \mathrm{bc}$ & $1460 \mathrm{c}$ \\
50 & $1370 \mathrm{~b}$ & $1550 \mathrm{bc}$ & $1460 \mathrm{c}$ \\
100 & $1580 \mathrm{ab}$ & $1780 \mathrm{ab}$ & $1680 \mathrm{~b}$ \\
150 & $1650 \mathrm{a}$ & $1750 \mathrm{~b}$ & $1870 \mathrm{a}$ \\
200 & $1730 \mathrm{a}$ & $2000 \mathrm{a}$ & $1650 \mathrm{~b}$ \\
250 & $1570 \mathrm{ab}$ & $1730 \mathrm{~b}$ & \\
\hline 300 & $1467 \mathrm{~B}^{+}$ & $1682 \mathrm{~A}$ & \\
\hline
\end{tabular}

** Values within the same columns followed by different small letters are significantly different based on Duncan's test at $\mathrm{P}<0.01$.

+ Values within the same row followed by different capital letters are significantly different based on Duncan's test at $\mathrm{P}<0.05$

The crude protein yield was calculated by multiplying the crude protein ratio and dry matter yield and the highest crude protein yield was obtained at the nitrogen rate of $250 \mathrm{~kg} \mathrm{ha}^{-1}$ in the first year, in the second year and in two-year average. In general, the crude protein yields of the plots with high crude protein content and dry matter yield were high as expected (Table 5).

Crude protein yield of annual ryegrass was reported as $1200 \mathrm{~kg} \mathrm{ha}^{-1}$ by Alvim and Moojen (1984), as $1290 \mathrm{~kg} \mathrm{ha}^{-1}$ by Basbug (1990), as $470 \mathrm{~kg} \mathrm{ha}^{-1}$ by Karakurt and Ekiz (1991), as $1150 \mathrm{~kg} \mathrm{ha}^{-1}$ by Kusvuran and Tansi (2005), as $800 \mathrm{~kg} \mathrm{ha}^{-1}$ by Bright et al. (2007), as $920 \mathrm{~kg} \mathrm{ha}^{-1}$ by Kesiktas (2010), as $820 \mathrm{~kg} \mathrm{ha}^{-1}$ by Kusvuran et al. (2014), and as $680 \mathrm{~kg} \mathrm{ha}^{-1}$ by Colak and Sancak (2017). The results obtained in this study do not comply with the results listed above. It can be concluded that the difference in crude protein yields is not surprised as the trials were carried out in regions with different ecological characteristics, distinctive applications were performed, and different cultivars were tested.

\section{ADF Concentration (\%)}

According to the one way ANOVA results, ADF concentration was not affected by the nitrogen fertilizer rate in the first year and in the second year. Nonetheless, nitrogen fertilizer application rates had a significant effect on two-year average ADF 
concentration values. The average ADF concentration values determined according to the nitrogen rates are given in Table 8.

According to the two-year averages, the ADF content was significantly higher at nitrogen rates of $50 \mathrm{~kg} \mathrm{ha}^{-1}$ and $100 \mathrm{~kg} \mathrm{ha}^{-1}$ compared to $150 \mathrm{~kg} \mathrm{ha}^{-1}$ nitrogen application rate. However, the ADF concentrations at $0,200,250$, and $300 \mathrm{~kg} \mathrm{ha}^{-1}$ nitrogen rates were not different from both higher or lower concentrations of 50, 100 or $150 \mathrm{~kg} \mathrm{ha}^{-1}$ doses. The mean ADF concentration in the first year was significantly higher than in the second year (Table 8). This may be due to the fact that the second falling rainfall and relative humidity are higher than the first year (Table 1).

Table 8. Average ADF concentration (\%) values of annual ryegrass based on nitrogen fertilizer rates

\begin{tabular}{c|c|c|c}
\hline \multirow{2}{*}{$\begin{array}{c}\text { Nitrogen } \\
\left.\text { (kg ha-1 }^{-1}\right)\end{array}$} & $\mathbf{2 0 1 5}$ & $\mathbf{2 0 1 6}$ & Mean \\
\cline { 2 - 4 } & 33.64 & 33.65 & $33.64 \mathrm{ab}^{*}$ \\
50 & 34.72 & 34.66 & $34.69 \mathrm{a}$ \\
100 & 34.62 & 34.81 & $34.71 \mathrm{a}$ \\
150 & 33.86 & 33.33 & $33.59 \mathrm{~b}$ \\
200 & 35.95 & 33.72 & $34.65 \mathrm{ab}$ \\
250 & 34.36 & 33.31 & $33.83 \mathrm{ab}$ \\
300 & 34.15 & 33.40 & $33.78 \mathrm{ab}$ \\
\hline Mean & $34.42 \mathrm{~A}+$ & $33.84 \mathrm{~B}$ & \\
\hline
\end{tabular}

* Values within the same columns followed by different small letters are significantly different based on Duncan's test at $\mathrm{P}<0.05$.

+ Values within the same row followed by different capital letters are significantly different based on Duncan's test at $\mathrm{P}<0.05$

ADF concentrations of the annual ryegrass reported by Caddel and Allen (1997) were $31.0-35.0 \%$, by Meeske et al. (2009) were 31.4\%-32.3, by Kusvuran et al. (2014) was $37.4 \%$, by Colak and Sancak (2017) were 31.1-32.1\%, and by Ozdemir et al. (2019) were 30.5-34.2. The results obtained in this study are in agreement with Caddel and Allen (1997) and Ozdemir et al. (2019) but not with other studies. The difference can be attributed to the change in the cellulose and lignin contents of the cultivars along with the different ecological conditions and harvest regimen.

\section{NDF Concentration (\%)}

According to the ANOVA results of NDF concentrations based on different nitrogen rates, the first year and the second year nitrogen rates did not affect the NDF concentrations. Nevertheless, nitrogen rates had a significant effect on the two-year average NDF concentrations in annual ryegrass (Table 9).

According to the two-year averages, the NDF composition of the herbage at $200 \mathrm{~kg} \mathrm{ha}^{-1}$ nitrogen rate was significantly higher than that of the control and 250 to $300 \mathrm{~kg} \mathrm{ha}^{-1}$ nitrogen rates (Table 9).

Van Soest (1985) stated that in order to ensure optimum milk yield in dairy cattle, NDF composition should be 36\%. Yavuz (2005) affirmed that the amount of feed digested by the animal decreased with the increase in NDF ratio and the increase in NDF ratio in roughage caused a decrease of $1-2 \%$ of milk yield. Thus, it can be concluded that due to the high NDF composition, annual ryegrass alone is not suitable for feeding dairy cattle. 
NDF composition in annual ryegrass was reported to be in the range of $47.7-54.7 \%$ by Viviani Rossi et al. (1994), was in the range of 40-46\% according to Caddel and Allen (1997), was in the range of 42.2-50.6\% in Teutsch and Smith (2001), was 47\% in Meeske (2009), was 58.7\% in Kusvuran and Tansi (2005), was 59.6\% in Simsek (2015), and was in the range of 56.01-54.14\% in Colak (2015). The results obtained in the current research did not show compliance with Caddel and Allen (1997), Meeske (2009), Kusvuran et al. (2014), Simsek (2015): however, they were in agreement with the Viviani Rossi et al. (1994), Teutsch and Smith (2001) and Colak (2015). It can be concluded that the differences in NDF composition can be attributed to the fact that the trials were carried out in regions with different ecological characteristics, with distinctive applications, and different cultivars.

Table 9. Average NDF concentrations (\%) of annual ryegrass based on nitrogen fertilizer rates

\begin{tabular}{c|c|c|c}
\hline \multirow{2}{*}{$\begin{array}{c}\text { Nitrogen } \\
\left(\mathbf{k g ~ h a}^{-1}\right)\end{array}$} & \multicolumn{2}{|c}{ Years } & Mean \\
\cline { 2 - 4 } & $\mathbf{2 0 1 5}$ & $\mathbf{2 0 1 6}$ & $53.10 \mathrm{~b}^{*}$ \\
0 & 54.85 & 51.35 & $55.12 \mathrm{ab}$ \\
100 & 55.23 & 55.02 & $54.87 \mathrm{ab}$ \\
150 & 55.40 & 54.34 & $54.95 \mathrm{ab}$ \\
200 & 55.43 & 54.47 & $56.42 \mathrm{a}$ \\
250 & 56.38 & 56.45 & $53.81 \mathrm{~b}$ \\
300 & 54.23 & 53.39 & $53.59 \mathrm{~b}$ \\
\hline Mean & 53.28 & 53.90 & \\
\hline
\end{tabular}

* Values within the same columns followed by different small letters are significantly different based on Duncan's test at $\mathrm{P}<0.05$

\section{Digestible Dry Matter Ratio (\%)}

One way ANOVA analyses targeting the effect of nitrogen rate on digestible dry matter ratio revealed that different nitrogen rate did not lead a significant difference in the digestible dry matter ratios in the first and in the second years whereas a significant difference was observed among the nitrogen rates for the analysis of values averaged over two years (Table 10).

As indicated in Table 10, the average digestible dry matter ratio varied between $61.85 \%$ and $62.72 \%$ for the two-year averages depending on the nitrogen rates applied. The highest DDM ratio was found at $150 \mathrm{~kg} \mathrm{ha}^{-1}$ nitrogen dose and the lowest was at $100 \mathrm{~kg} \mathrm{ha}^{-1}$ nitrogen dose. The mean DDM ratio in the second year was significantly higher than the one in the first year. As expected, the rate of digestible dry matter, which was negatively correlated with the ADF composition of the herbage, was higher in the nitrogen dose with low ADF and higher in the year with the low ADF composition (Table 8).

\section{Digestible Dry Matter Yield ( $\left.\mathrm{kg} \mathrm{ha}^{-1}\right)$}

Nitrogen rate significantly affected digestible dry matter yield in the first year, in the second year, in average over the two years (Table 11).

The digestible dry matter yield increased in annual ryegrass in parallel to nitrogen application rate. In the first year, the digestible dry matter yield at $250 \mathrm{~kg} \mathrm{ha}^{-1}$ nitrogen rate was significantly higher than the those of rates other than 150 and $200 \mathrm{~kg} \mathrm{ha}^{-1}$. In the second year, the digestible dry matter yield at $250 \mathrm{~kg} \mathrm{ha}^{-1}$ nitrogen rate was 
significantly higher than those in rates other than $200 \mathrm{~kg} \mathrm{ha}^{-1}$. In the two-year average values, the digestible dry matter yield at $250 \mathrm{~kg} \mathrm{ha}^{-1}$ nitrogen rate was significantly higher than in all other nitrogen rates (Table 11).

Digestible dry matter yield is a variable that depends on digestible dry matter content and dry matter yield. Therefore, digestible dry matter yield was high when both digestible dry matter ratio and dry matter yield were high (Table 5, Table 10).

Table 10. Digestible dry matter ratios (\%) of annual ryegrass based on nitrogen fertilizer rates

\begin{tabular}{c|c|c|c}
\hline \multirow{2}{*}{$\begin{array}{c}\text { Nitrogen } \\
\left(\text { kg ha }^{-1}\right)\end{array}$} & \multicolumn{3}{|c}{ Years } \\
\cline { 2 - 4 } & $\mathbf{2 0 1 5}$ & $\mathbf{2 0 1 6}$ & Mean \\
\hline 0 & 62.69 & 62.68 & $62.68 \mathrm{ab}^{*}$ \\
50 & 61.85 & 61.89 & $61.87 \mathrm{~b}$ \\
100 & 61.92 & 61.78 & $61.85 \mathrm{~b}$ \\
150 & 62.51 & 62.93 & $62.72 \mathrm{a}$ \\
200 & 61.16 & 62.63 & $61.90 \mathrm{ab}$ \\
250 & 62.13 & 62.95 & $62.54 \mathrm{ab}$ \\
300 & 62.29 & 62.87 & $62.58 \mathrm{ab}$ \\
\hline Mean & $62.08 \mathrm{~B}^{+}$ & $62.53 \mathrm{~A}$ & \\
\hline
\end{tabular}

* Values within the same columns followed by different small letters are significantly different based on Duncan's test at $\mathrm{P}<0.05$.

+ Values within the same row followed by different capital letters are significantly different based on Duncan's test at $\mathrm{P}<0.05$

Table 11. Average digestible dry matter yield values $\left(\mathrm{kg} \mathrm{ha}^{-1}\right)$ of annual ryegrass based on nitrogen fertilizer rates

\begin{tabular}{c|c|c|c}
\hline \multirow{2}{*}{$\begin{array}{c}\text { Nitrogen } \\
\left(\mathbf{k g ~ h a}^{-1}\right)\end{array}$} & $\mathbf{2 0 1 5}$ & $\mathbf{2 0 1 6}$ & Mean \\
\cline { 2 - 4 } & $5370 \mathrm{~d}^{* *}$ & $7110 \mathrm{c}$ & $6240 \mathrm{e}$ \\
50 & $6500 \mathrm{bc}$ & $7470 \mathrm{bc}$ & $6985 \mathrm{~cd}$ \\
100 & $6080 \mathrm{~cd}$ & $7040 \mathrm{c}$ & $6560 \mathrm{de}$ \\
150 & $7000 \mathrm{abc}$ & $7900 \mathrm{bc}$ & $7450 \mathrm{bc}$ \\
200 & $7260 \mathrm{ab}$ & $8130 \mathrm{ab}$ & $7695 \mathrm{~b}$ \\
250 & $7710 \mathrm{a}$ & $8970 \mathrm{a}$ & $8340 \mathrm{a}$ \\
300 & $6620 \mathrm{bc}$ & $7260 \mathrm{bc}$ & $6940 \mathrm{~cd}$ \\
\hline Mean & $6648 \mathrm{~B}^{+}$ & $7697 \mathrm{~A}$ & \\
\hline
\end{tabular}

** Values within the same columns followed by different small letters are significantly different based on Duncan's test at $\mathrm{P}<0.01$.

+ Values within the same row followed by different capital letters are significantly different based on

Duncan's test at $\mathrm{P}<0.05$

\section{Relative Feed Value (RFV)}

According to the ANOVA results, nitrogen rates did not significantly affect the relative feed value in the first year. Nonetheless, relative feed values of the second year and two-year averages indicated that nitrogen rates had a significant effect on relative feed values in annual ryegrass (Table 12).

In the second year of the study and at the two-year averages, the lowest RFV was obtained from $200 \mathrm{~kg} \mathrm{ha}^{-1}$ nitrogen application. The relative feed value is calculated using the ADF and NDF ratios and has a negative correlation with the ADF and NDF ratios. Therefore, a high relative feed value is expected at low ADF and NDF composition values. 
Colak and Sancak (2017) reported RFV of 111.2 in annual ryegrass at $240 \mathrm{~kg} \mathrm{ha}^{-1}$ nitrogen rate in a study conducted in Ankara. Kusvuran et al. (2014) reported RFV of 94.0 in annual ryegrass. RFV obtained from the present study is lower than the values reported in Colak and Sancak (2017) and higher than those reported in Kusvuran et al. (2014).

Caddel and Allen (1997) reported the relative feed value of completely headed wheat as lower than 77. Schroeder (2004) stated that the relative feed value decreases as the harvest time delayed, and Linn and Martin (1999) argued that the relative feed value of forage for high-milk yield dairy cows should be at least 124 . The RFV obtained from the current study is below the stated value. RFV is a value obtained from ADF and NDF values. It is inversely proportional to $\mathrm{ADF}$ and $\mathrm{NDF}$, and low RFV is obtained from high ADF and NDF values.

Table 12. The average RFV of annual ryegrass based on nitrogen fertilizer rates

\begin{tabular}{c|c|c|c}
\hline \multirow{2}{*}{$\begin{array}{c}\text { Nitrogen } \\
\left(\text { kg ha }^{-1}\right)\end{array}$} & \multicolumn{3}{|c}{ Years } \\
\cline { 2 - 4 } & $\mathbf{2 0 1 5}$ & $\mathbf{2 0 1 6}$ & Mean \\
\hline 0 & 106.4 & $114.5 \mathrm{a}$ & $110.4 \mathrm{a} * *$ \\
10 & 104.2 & $104.6 \mathrm{~b}$ & $104.4 \mathrm{bc}$ \\
150 & 104.0 & $105.8 \mathrm{~b}$ & $104.9 \mathrm{bc}$ \\
200 & 105.0 & $107.5 \mathrm{ab}$ & $106.2 \mathrm{abc}$ \\
250 & 100.9 & $103.3 \mathrm{~b}$ & $102.1 \mathrm{c}$ \\
300 & 106.5 & $109.6 \mathrm{ab}$ & $108.1 \mathrm{ab}$ \\
Mean & 108.9 & $108.5 \mathrm{ab}$ & $108.7 \mathrm{ab}$ \\
\hline
\end{tabular}

** Values within the same columns followed by different small letters are significantly different based on Duncan's test at $\mathrm{P}<0.01$

\section{Conclusions}

Forage crops produced in Turkey are not enough for animals. Therefore, meat and milk production is low. Annual ryegrass is a high yield and high quality alternative fodder plant due to its high growth rate and ability to absorb nitrogen. Annual ryegrass, fertilizer is a forage plant with high yield. The production of forage crops may increase with the determination of suitable fertilizer feeds. Meat and milk production can be increased by increasing forage crop production.

In this research, we aimed to determine the optimum rate of nitrogen fertilization to achieve high yield and high quality forage from annual ryegrass (Lolium multiflorum L.) in the Central Black Sea Climate Zone in Turkey. According to the results of the research, we conclude that (i) it is possible to obtain high yield and high forage quality with nitrogen fertilization under the conditions of Central Black Sea Climate Zone, (ii) application of $250 \mathrm{~kg} \mathrm{ha}^{-1}$ nitrogen rate is appropriate for high yield, (iii) increasing nitrogen doses do not affect the ADF and NDF rates, and (iv) yield decreases with $300 \mathrm{~kg} \mathrm{ha}^{-1}$ nitrogen application rate but the crude protein yield increases. For the annual ryegrass, $250 \mathrm{~kg} \mathrm{ha}^{-1}$ nitrogen rate is recommended to achieve high yield in the Central Black Sea Climate Zone in Turkey and possibly in similar ecological conditions. 


\section{REFERENCES}

[1] Acikgoz, E. (2001): Forage Crops. - Uludag University Empowerment Foundation Publication No: 182, VIPAS Publication No: 58, Bursa, 180-187p.

[2] Alvim, M. J., Moojen, E. L. (1984): Effects of sources and rates of nitrogen and management practices on production and quality of ryegrass forages. - Herbage Abst 56: 387.

[3] Anonymous (2001): Ministry of Agriculture and Forestry, TTSM Technical Instructions. - https://www.tarimorman.gov.tr/BUGEM/TTSM/Sayfalar/Detay.aspx?SayfaId=62 (Last access:30.05.2019).

[4] Anonymous (2017): Meteorology Provincial Directorate records, Tokat.

[5] Avcioglu, R., Geren, H. (1996): Forage plants. - Harvest Publishing, İzmir.

[6] Bartholomew, P. W., Willams, R. J. (1978): Nitrogen Requirement for Direct Drilled Ryegrass. - Joint Agricultural Research \& Development Project, University College of North Wales, Bangor, UK and Ministry of Agriculture \& Water, Saudi Arabia. Publication No.: 129.

[7] Basbug, S. (1990): Research on the yield and quality of some perennial and one-year grasses forage crops in Bursa conditions. - Master Thesis, Uludag University Institute of Science and Technology, Bursa.

[8] Baytekin, H., Kizılsimsek, M., Demiroglu, G. (2009): Grass and Discrete Types. - In: Avcioğlu, R., Hatipoğlu, R., Karadağ, Y. (eds.) Forage Crops General Chapter Volume III. Ministry of Agriculture and Rural Affairs General Directorate of Agricultural Production and Development, Izmir, p. 561-572.

[9] Bright, J., Desikan, R., Hancock, J. T., Weir, I. S., Neill, S. J. (2006): ABA-induced NO generation and stomatal closure in Arabidopsis are dependent on $\mathrm{H}_{2} \mathrm{O}_{2}$ synthesis. - The Plant Journal 45: 113-122.

[10] Caddel, J., Allen, E. (1997): Froge Quality İnterpretations. http://virtual.chapingo.mx/dona/paginaCBasicos/f-2117.pdf. (Last Access: 14.03.2016).

[11] Celen, A. E. (1991): Possibilities to benefit from one-year grass (Lolium multiflorum var. Westerwoldicum) in Aegean Region conditions. - Turkey 2. Grassland and Forage Crops Congress, 28-31 May 1991, EU Printing, İzmir, 424-4 29 p.

[12] Cinar, S., Avci, M., Hatipoglu, R., Kizil Aydemir, E. S. (2011): A Research on Hay Yields of Some One - Year Grass Varieties. - 9. Field Crops Congress, Bursa 3: 18641867.

[13] Colak, E. (2015): Effect of nitrogen fertilizer doses on grass yield, quality and some agricultural properties of grass (Lolium italicum L.) varieties. - Ankara University, Institute of Science and Technology, Field Crops Department, Ph.D. Thesis, 62 p Ankara.

[14] Colak, E., Sancak, C. (2017): Effect of nitrogen fertilizer doses on grass quality of grass (Lolium italicum L.) varieties. - Mediterrenean Agri. Sci. 30(3): 245-251.

[15] Corainville, R. C. D., Mauet, A., Plancquaert, P. (1973): The intensive use of fertilizer for Ryegrass in the west. - Bulletin Technique d'information 281: 499-504.

[16] Demiroglu, G., Avcioglu, R., Kir, B., Geren, H., Budak, B., Kavut, Y. T. (2007): A study on the performance of some grass forage crops in Mediterranean climate conditions. Turkey VII. Field Crops Congress, 25-27 June 2007, Erzurum.

[17] Duzgunes, O., Kesici, T., Kavuncu, O., Gürbüz, F. (1987): Research and Experimental Methods. - Ankara University, Faculty of Agriculture, Textbook Publication No. 1021, p. 381, Ankara.

[18] Erkun, V. (1954): Seed Production Methods of Meadow and Rangeland Plants. - Central Research Institute of Animal Husbandry, Ankara.

[19] Genckan, M. S. (1983): Forage Crops Agriculture. - Ege University Faculty of Agriculture, p. 520, Izmir.

[20] Gokmen, S., Sencar, Ö., Sakin, M. A. (2001): Rersponse of Popcorn (Zea mays evarta) to Nitrogen Rates and Plant Densities. - Türk J. Agric. For. 25: 15-23. 
[21] Kacar, B. (2016): Plant, Soil and Fertilizer Analysis. - Nobel Publications, Publication No.: 1524, Ankara.

[22] Kallenbach, R., Massie, M., Crawford, R. (2003): Nitrogen fertilization strategies for annual ryegrass pastures. - University of Missouri Extension.

[23] Karakurt, E., Ekiz, H. (1991): The effect of mixture of Alexandria trifolium (Trifolium alexandrinum L.) and grass (Lolium multiflorum Lam.) on herbage yield. - Ankara University, Faculty of Agriculture 1999(44): 97-104.

[24] Kesiktas, M. (2010): The effects of different sowing times and nitrogen fertilizer dose applications on the yield of grass (Lolium multiflorum westervoldicum Caramba) in Karaman. - Cukurova University, Institute of Science and Technology, Field Crops Department, Master Thesis, 59 p., Adana.

[25] Kun, E. (1994): Cereals II (Warm season Cereals). - Ankara University Faculty of Agriculture Publications, 1452, Ankara.

[26] Kusvuran, A., Tansi, V. (2005): Determination of the effect of different form number and nitrogen dose on one-year grass (Lolium multiflorum cv. Caramba) grass and seed yield in Cukurova conditions. - Turkey VI. Field Crops Congress, 5-9 September 2005, Antalya, Research Presentation II: 797-802.

[27] Kusvuran, A. (2011): The effects of different nitrogen doses on herbage and seed yields of annual ryegrass (Lolium multiflorum cv. Caramba). - African Journal of Biotechnology 10(60): 12916-12924.

[28] Kusvuran, A., Kaplan, M., Nazl1, R. İ. (2014): Effects of ratio and row spacing in hungarian vetch (Vicia pannonica Crantz.) and annual ryegrass (Lolium multiflorum Lam.) intercropping system on yield and quality under semi arid climate conditions. Turkish Journal of Field Crops 19(1): 118-128.

[29] Linn, J. G., Martın, N. P. (1999): Forage Quality Tests and Interpretations. - In: Kallenbach, R., Massie, M., Crawford, R. (eds.) Nitrogen fertilization strategies for annual ryegrass pasture. University of Missouri Extension, USA.

[30] Meeske, R., Botha, P. R., Van Der Merwe, G. D., Greyling, J. F., Hopkins, C., Marais, J. P. (2009): Milk production potential of two ryegrass cultivars with different total nonstructural carbohydrate contents. - South African Journal of Animal Science 39(1).

[31] Ozdemir, S., Budakl1, Carpici, E., Asik, B. B. (2019): Effects of Different Nitrogen Doses on Herb Yield and Quality of Grass. - KSU J.Agric. Nat 22(1): 131-137.

[32] Ozkul, H., Kirkpinar, F., Tan, K. (2012): The use of Caramba (Lolium multiflorum cv. Caramba) grass in ruminant feeding. - Animal Production 53(1): 21-26.

[33] Parlak, A. O., Akgul, F., Gokkus, A. (2007): The effects of sowing and nitrogen fertilization on one year grass (Lolium multiflorum Lam.) Grass yield and quality under different row spacing in Ankara conditions. - Turkey VII. Field Crops Congress, 25-27 June 2007, Erzurum, Presentation with Presentation: 139-142 p.

[34] Pavinato, P. S., Restelatto, R., Sartor, L. R., Paris, W. (2014): Production and nutritive value of ryegrass (cv. Barjumbo) under nitrogen fertilization. - Revista Ciência Agronômica 45(2): 230-237.

[35] Piskin, M. (2007): Effects of different seed amounts on yield and some yield components of perennial grass (Lolium multiflorum Lam). - Master Thesis. Selcuk University. Graduate School of Natural and Applied Sciences, Konya, 46 p.

[36] Schroeder, J. W. (2004): Forage Nutrition for Ruminants, AS-1250. www.ag.ndsu.edu.tr. (Last access: 24.01.2012).

[37] Seker, H. (1992): Effects of different nitrogen doses and seed amounts on the yield and some chemical properties of the grass in Multimo cultivar (Lolium multiflorum Lam.). Atatürk University, Institute of Science and Technology, Field Crops Department, Master Thesis, 52 p., Erzurum.

[38] Serin, Y., Tan, M. (2001): Introduction to Forage Crop Culture. - Atatürk University Faculty of Agriculture Publications, No: 206, 217 p., Erzurum. 
[39] Sheaffer, C. C., Peterson, M. A., Mc Caslin, M., Volenec, J. J., Cherney, J. H., Johnson, K. D., Woodward, W. T., Viands, D. R. (1995): Acid detergent fiber, neutral detergent fiber concentration and relative feed value. - Available from URL: https://www.umvotiagri.co.za/linked/adf\%20ndf\%20in\%20silage.pdf. (Last access 23.12.2014).

[40] Simic, A., Vucković, S., Kresović, M., Vrbničanin, S., Božić, D. (2009): Changes of crude protein content in ryegrass influenced by spring nitrogen application. Biotechnology in Animal Husbandry 25(5-6): 1171-1179.

[41] Simsek, S. (2015): A study on the effects of different Hungarian vetch (Vicia pannonica Crantz) and one-year turf (Lolium multiflorum Lam.) Mixture ratios on yield and quality in Kurşehir conditions. - Ahi Evran University, Institute of Science and Technology, Field Crops Departmen, Kırşehir.

[42] Sleugh, B., Moore, K. J., George, J. R., Brummer, E. C. (2000): Binary legume - grass mixtures improve forage yield, quality, and seasonal distribution. - Agronomy Journal 92: 24-29.

[43] TAN (1995): The determination of nitrogen according to kjeldahl using block digestion and steam distilation. - Tecator Application Note AN 300, Tecator AB Sweden: 1-11.

[44] Teutsch, C., Smith, R. (2001): Does annual ryegrass fit into Virginia's pasture systems? Crop and soil environmental news, September, USA.

[45] Van Soest, P. J., Robertson, J. B., Lewis, B. A. (1991): Methods for Dietary Fiber, Neutral Detergent Fiber, and Nonstarch Polysaccharides in Relation to Animal Nutrition. - J. Dairy Sci. 74: 3583-3597.

[46] Viviani Rossi, E. M., Gutierrez, L. M., Moreno, E., Mazzanti, A. (1994): Nitrogen fertilizer effects upon silage composition and quality of Lolium multiflorum L. - CC 276 (7620) Argentina.

[47] Yavuz, M. (2005): Detergent Fiber System. - Journal of Gaziosmanpasa University, Faculty of Agriculture 22(1): 93-96. 